\title{
Minimizing Employment Taxes in U.S. "S" Corporations: Levels of Compensation and Shareholder Sophistication
}

\author{
Andrew M. Brajcich ${ }^{1} \&$ Daniel Lawson ${ }^{1}$ \\ ${ }^{1}$ School of Business Administration, Gonzaga University, Spokane, United States \\ Correspondence: Andrew M. Brajcich, School of Business Adminstration, Gonzaga University, 502 East Boone \\ Avenue, AD 9, Spokane, WA 99258, USA. Tel: 1-509-313-7053. E-mail: brajcicha@gonzaga.edu
}

Received: December 17, 2012

Accepted: December 31, 2012

Online Published: January 25, 2013

doi:10.5539/ibr.v6n3p1

URL: http://dx.doi.org/10.5539/ibr.v6n3p1

\begin{abstract}
In the U.S., firm owners operating as an S corporation may minimize the incurrence of employment tax by reducing compensation paid to shareholder-employees and increasing the amount of tax-free distributions from the firm. While the U.S. limits a taxpayer's ability to use this technique, many firm owners are still able to reduce employment tax expense to some degree. Using the U.S. Federal Reserve's 2003 Survey of Small Business Finances, we find that more sophisticated $\mathrm{S}$ corporation owners make use of this tax planning technique than their counterparts operating in $\mathrm{C}$ corporations.
\end{abstract}

Keywords: $\mathrm{s}$ corporation, officer compensation, employment tax, tax planning

\section{Introduction}

In the United States (U.S.), firms classified as corporations for tax purposes will generally have earnings taxed twice: once at the corporate level when earned and again at the shareholder level when a dividend distribution is made. In contrast, firms operating as a pass-through entity in the U.S. will not be subject to tax at the firm level. Instead, income earned will generally pass through to the owners in proportion to their ownership interest in the firm and is taxed only once at the owner level. Because operating in corporate form offers many non-tax benefits, including a familiar organizational structure and limitation of liability, many firm owners still choose to operate in corporate form despite the double tax detriment. Fortunately, the U.S. permits corporations meeting certain qualifications to make a "Subchapter S election" and be treated as a pass-through entity for tax purposes. This election in many ways offers the best of both worlds for some taxpayers: a corporation with profits only taxed once.

Qualifying corporations making the S election are known as S corporations. Generally, profits of the corporation are taxed to the owners when earned by the $\mathrm{S}$ corporation whether or not the corporation makes any distribution to its shareholders. Subsequent distributions of previously taxed earnings are generally received by the shareholders tax-free.

The U.S. imposes a limit on the number of shareholders an S corporation may have. In fact, $\mathrm{S}$ corporations are legally titled "Small Business Corporations." Historically, owners of small, closely-held firms often work in the organization in a management position or as a key officer (Plesko, 1995). As employees, any compensation received is subject to federal employment taxes in the U.S., namely Social Security and Medicare. These employment taxes can be as much as $15.3 \%$ of compensation in addition to any income tax levied, all of which is ultimately borne by the shareholders in the pass-through context. As a result, shareholder-employees of $\mathrm{S}$ corporations have often utilized a tax planning technique to reduce the incurrence of employment taxes: pay less salary to shareholder-employees while making larger distributions of previously taxed income. This strategy has the effect of reducing compensation and thus the gross amount against which employment taxes are levied while maintaining the amount of monies received by the shareholder-employees from the $\mathrm{S}$ corporation. The U.S. Internal Revenue Service (IRS) limits the S corporation shareholder's ability to do use this technique by requiring reasonable compensation be paid under the facts and circumstances of employment. To be sure, the IRS requires S corporations to specifically report the amount of compensation paid to officers. This reasonable compensation standard is question of fact that gives $\mathrm{S}$ corporation owner-employees some latitude in structuring their compensation and thus, tax planning opportunities arise. 
In a previous study, we looked at the utilization of debt as a method to reduce tax expense in the U.S. and the level of sophistication of owners using debt capitalization techniques (Brajcich \& Lawson, 2012). That study found debt capitalization of corporations is a complex tax planning tool that most owners would not employ without some degree of sophistication. Likewise, the use of reduced S corporation compensation packages to shareholder-employees coupled with higher distributions to shareholders is a complex tax planning technique. Here, using the 2003 Survey of Small Business Finances by the U.S. Federal Reserve Board (SBBF), we look at the level of compensation paid to S corporation shareholder-employees. For the more sophisticated firm owner operating in an S corporation, we would expect to see lower levels of compensation. For corporations that have not made the $\mathrm{S}$ election, we would not expect to see similar results as any tax advantage of reduced compensation and increased dividends is mitigated by the double tax regime imposed on such corporations, commonly referred to as $\mathrm{C}$ corporations.

Our results are varied. When using the graduate degree as a proxy for sophistication as done in our previous study (Brajcich \& Lawson, 2012), we find that $\mathrm{C}$ corporations compensate their officers more than average to a statistically significant degree, while $\mathrm{S}$ corporations compensate their officers less than average. Surprisingly, $\mathrm{S}$ corporations do not compensate officers below average at a statistically significant level. Using the college degree and age of the firm as additional proxies, we find that $\mathrm{C}$ corporations compensate their shareholders two to three times as much as $\mathrm{S}$ corporations.

We also look at results from a sub-sample that excludes firms that do not compensate their officers. This approach should produce results more representative of our hypothesis because of IRS rules surrounding officer compensation by S corporations. Specifically, a firm owner seeking to take advantage of this strategy to limit employment taxes must pay its officers a reasonable compensation. Rarely is zero compensation reasonable when working for a firm and to work for free as an S corporation owner would bring increased scrutiny by the IRS. Compensation of S corporation officers has been a recent enforcement priority of the IRS (Rettig, 2010). When looking at firms that compensate their officers, we see similar results, i.e., C corporations pay more compensation to a statistically significant degree while $\mathrm{S}$ corporations pay less, but not to a statistically significant degree.

When looking at the experience of the firm owner, however, the results are not what we would expect. We find that with increased experience, $\mathrm{S}$ corporations compensation of officers is higher than average at a statistically significant level. As noted in our previous study, experience may be a proxy for business savvy, but does not necessarily translate to sophistication in the tax planning sense (Brajcich \& Lawson, 2012).

\section{Literature Review}

The challenges and characteristics of small businesses are very different from those of large businesses (Ang, 1991). Small businesses are often closely-held and tax considerations are likely to have a greater bearing on the choice of entity in the small business context (Ayers, Cloyd, \& Robinson, 1996) and (Carroll \& Joulfaian, 1997). Although the small firm is a separate legal entity from its owner, the interrelations between owner and firm result in many common interests between both parties. For example, compensation to owners of S corporationsmay be postponed during formative years as these owners are more likely to be indifferent to receiving compensation or profit distributions and can integrate personal incomes to minimize personal taxes (Ang, 1991).

Given that tax is a pertinent consideration for small business, tax practitioners and owners alike seek to minimize small business tax expense. After the Tax Reform Act of 1986, the U.S. saw a rise in elections to be S corporations that is largely attributable to the increased corporate tax rates (Carroll \& Joulfaian, 1997). While many studies have looked to the pass-through characteristic of S corporations and differential tax rates between individuals and corporations as driver in their increased popularity (Plesko, 1996), few have observed the use of specific tax planning opportunities with respect to employment tax. A multitude of law review articles have looked at the issue of reasonable compensation in the S corporation context, e.g. Bertozzi (1978), or IRS enforcement, e.g. Watters and Burckel (1991), but we find no empirical study on point that looks at the use of the employment tax reduction technique analyzed here.

\section{Methodology}

We begin by regressing compensation of S- and C-corporations to shareholders on sophistication and education variables using ordinary least squares. The first regression to estimate is:

$$
\text { comp }_{i}=\delta+\delta_{2} \text { firm_age }_{i}+\delta_{3} \text { college }_{i}+\delta_{4} \text { graduate }_{i}+\delta_{5} \text { bus_exper }_{i}+\varepsilon_{i}
$$


where: $\operatorname{comp}_{i}$ is the total amount of officers' compensation/guaranteed payments to shareholder-employees for firm $i$; firm_age $e_{i}$ is the age of the firm in years scaled by 10 ; college $_{i}$ is a dummy variable that equals one if the owner of the firm has a college degree and zero otherwise; graduate $_{i}$ is a dummy variable that equals one if the owner of the firm has a graduate degree and zero otherwise, and bus_exper ${ }_{i}$ is the owner business experience in years scaled by $10 . \varepsilon_{i}$ is the error term for firm $i$. $\delta$ 's are coefficients to be estimated. We report the results from this regression in Table 1.

In a second regression model, we exclude firms that report non-positive compensation to shareholders and repeat the regression above in an effort to estimate the marginal effects sophistication and education have on $\mathrm{C}$ - and S-corporations compensation to shareholders. We report the results from our second regression model in Table 2. In a third regression, we use a subsample of firms that are owned by a single individual and repeat regression (1). We report these regression results in Table 3. In the final regression model, we use single-owner firms that report positive compensation to shareholders and repeat the regression. We report our final regression results in Table 4.

\section{Data}

We use survey data from the SBBF, which is a random sample of 4,240 small businesses. (Note 1) Since the focus of our study is on S- and C-corporations, we exclude sole proprietors, LLCs and partnerships, leaving a sample of 2,893 firms. We also drop financially constrained firms, including firms with negative equity and firms that were consistently denied or discouraged from applying for loans or renewals of lines of credit, leaving a sample of 1,743 firms. We also drop 12 firms that report non-positive total assets. This leaves a final sample of 1,731 firms, including 1,067 S-Corporations and $664 \mathrm{C}$-Corporations for our first regression model.

We use compensation payments to shareholders as the dependent variable for all of our regression models. For sophistication proxies, we use the age of the firm in years and the number of years of business experience of the owner of the firm, each scaled by 10. To determine the extent education has on compensation, we use dummy variables for college and graduate degrees, where degree equals one if the firm owner has a degree. Since college degree and graduate degree are highly correlated to each other, we orthogonalize the two variables to avoid multi-collinearity problems.

\section{Results}

We report ordinary least squares regression results in Table 1 where the dependent variable is compensation to shareholders. Regression results for S-corporations are reported in column 1 and C-corporations in column 2. As the main goal of this study is to explore the significance of sophistication and education on compensation distribution within a S- and C-corporation, we begin by focusing on the age of the firm and whether or not the owner of the firm has a college or graduate degree. As reported in columns 1 and 2, older firms are associated with distributing additional compensation to their shareholders. For every 10-year increase in firm age, S-corporations distribute an additional $\$ 2,950$ in compensation to their shareholders, whereas C-corporations distribute more than twice that amount $(\$ 5,980)$, results that are statistically significant at the $5 \%$ and $1 \%$ level, respectively. Similarly, C-corporations that have owners with college degrees distribute nearly three times more compensation $(\$ 163,827$ versus $\$ 56,328$ ), on average, to their shareholders than S-corporations with college degree holding owners, results of which are significant at the $1 \%$ and $3 \%$ level, respectively. Furthermore, C-corporations with graduate degree holding owners distribute $\$ 287,292$ more compensation, on average, than C-corporations with non-graduate degree holding owners. This result is also statistically significant at the $1 \%$ level. The graduate degree variable is negative for S-corporations, however, the result is not statistically significant.

The results in Table 1 fit nicely with our hypotheses that sophistication and education are important factors with regards to mitigating the double tax regime with the exception of business experience. We find that a 10 -year increase in business experience for S-corporation owners is associated with an additional $\$ 2,896$ in compensation to shareholders, but a decrease of $\$ 4,279$ in compensation for C-corporation owners, results that are both significant at the $5 \%$ level. Based on our hypotheses, we expected the opposite. We offer no explanation here, only that experience may not necessarily translate to good tax planning. 
Table 1. Compensation of S- and C-corporations

\begin{tabular}{lll}
\hline Variables & S-Corporation Compensation & C-Corporation Compensation \\
\hline Firm Age & $2,950.47^{* *}$ & $5,979.55^{* * *}$ \\
& $(0.013)$ & $(0.001)$ \\
College Degree & $56,328.01^{* *}$ & $163,827.08^{* * *}$ \\
& $(0.018)$ & $(0.000)$ \\
Graduate Degree & $-33,840.02$ & $287,292.21^{* * *}$ \\
& $(0.301)$ & $(0.000)$ \\
Business Experience & $2,895.83^{* *}$ & $-4,278.77^{* *}$ \\
& $(0.017)$ & $(0.040)$ \\
Constant & $39,340.83$ & $167,926.97^{* * *}$ \\
& $(0.191)$ & $(0.005)$ \\
Observations & 1,060 & 625 \\
R-squared & 0.031 & 0.083 \\
\hline
\end{tabular}

Description: This table reports regression results of Compensation to shareholders on education and sophistication variables. Regression results for firms that file their taxes as S-corporations and C-corporations are displayed in columns 1 and 2, respectively. Firm Age is age of firm in years divided by 10 . College degree and Graduate degree are dummy variables that equal one if the owner of the firm has a college (graduate) degree and zero otherwise. Graduate degree and College degree are highly correlated and are thus orthogonalized to each other. Experience is the number of years of business experience of the primary owners divided by $10 . *, * *$ and $* *$ represent significance at the $10 \%, 5 \%$ and $1 \%$, respectively.

In Table 2, we report ordinary least squares regression results on a subsample of firms that have reported positive compensation to shareholders. By excluding the firms that award zero compensation to their shareholders, we are able to examine more closely the marginal effects sophistication and education has on compensation within Sand C-corporations. Similar to the results in Table 1, a 10-year increase in firm age corresponds to an additional $\$ 4,783$ in compensation within a C-corporation. However, unlike Table 1, the age of the S-corporation is not a statistically significant factor with respect to compensation, at least not within the $10 \%$ level. The owners of Scorporations (C-corporations) with college degrees are associated with an additional $\$ 73,202(\$ 186,505)$ in compensation to their shareholders, both results which are significant at the $1 \%$ level. For S-corporations, graduate degree continues to be an insignificant factor for compensation, while business experience continues to be a significant influence. A 10- year increase in experience is associated with a $\$ 3,807$ increase in compensation, a result which is significant at the $1 \%$ level. Graduate degree becomes an even greater factor for C-corporations, where $\$ 341,087$ additional compensation is associated with graduate degree holding owners. Business experience for C-corporations continues to be negative, however the statistical significance diminishes with this subsample.

Table 2. Subsample of S- and C-corporations with positive compensation

\begin{tabular}{lll}
\hline Variables & S-Corporation Compensation & C-Corporation Compensation \\
\hline Firm Age & $2,033.16$ & $4,783.15^{* *}$ \\
& $(0.148)$ & $(0.020)$ \\
College Degree & $73,201.86^{* * *}$ & $186,504.53^{* * *}$ \\
& $(0.010)$ & $(0.000)$ \\
Graduate Degree & $-34,519.80$ & $341,087.13^{* * *}$ \\
& $(0.375)$ & $(0.000)$ \\
Business Experience & $3,807.38^{* * *}$ & $-2,800.48$ \\
& $(0.009)$ & $(0.236)$ \\
Constant & $60,531.75^{*}$ & $184,583.41^{* * *}$ \\
& $(0.096)$ & $(0.005)$ \\
Observations & 877 & 541 \\
R-squared & 0.030 & 0.093 \\
\hline
\end{tabular}

Description: This table reports regression results of a subsample of firms for Compensation to shareholders on education and sophistication variables. The subsample includes firms that reported positive compensation. Regression results for firms that file their taxes as S-corporations and C-Corporations are displayed in columns 1 and 2, respectively. Firm Age, College degree, Graduate degree and Business Experience are as defined in Table $1 .{ }^{*}, * *$ and $* * *$ represent significance at the $10 \%, 5 \%$ and $1 \%$, respectively. 


\section{Conclusion}

Our results are varied. Using the graduate degree as a proxy for sophistication, we find that $\mathrm{C}$ corporations compensate their officers more than average to a statistically significant degree, while $\mathrm{S}$ corporations compensate their officers less than average, but not at a statistically significant level. Using the college degree and age of the firm as additional proxies, we find that $\mathrm{C}$ corporations compensate their shareholders two to three times as much as $\mathrm{S}$ Corporations.

When analyzing a sub-sample of only the firms that pay officer compensation we see similar results: C corporations pay more compensation to a statistically significant degree while $\mathrm{S}$ corporations pay less, but not to a statistically significant degree. This sub-sample should produce results more consistent with our hypothesis given the limitations placed on officer compensation by the IRS and related enforcement efforts.

Finally, looking at the experience of the firm owner, the results are not what we would expect. With increased experience, $\mathrm{S}$ corporations compensation of officers is higher than average at a statistically significant level. One possible explanation is that while experience may be a proxy for business savvy, it does not necessarily translate to sophistication in the tax planning sense or the regular and consistent use of tax planning professionals.

\section{References}

Ang, J. S. (1991). Small Business Uniqueness and the Theory of Financial Management. Journal of Small Business Finance, 1(1), 1-13.

Ayers, B. C., Cloyd, C. B., \& Robinson, J. R. (1996). Organizational Form and Taxes: An Empirical Analysis of Small Businesses. Journal of the American Taxation Association, (Supplement), 49-67.

Bertozzi, D. (1978). Compensation Policy for the Closely-Held Corporation: The Constraint of Reasonableness. American Business Law Journal, 16(2), 157-188. http://dx.doi.org/10.1111/j.1744-1714.1978.tb01107.x

Brajcich, A. M., \& Lawson, D. (2012). Utilizing Debt as a Tax Benefit: The Capitalization of U.S. Corporations and Owner Sophistication. Journal of Business, Economics and Finance, 1(4), 116-123.

Carroll, R., \& Joulfaian, D. (1997). Taxes and Corporate Choice or Organizational Form. OTA Paper, 73, U.S. Department of the Treasury.

Plesko, G. A. (1995). The Role of Taxes in Organizational Choice: S Conversions After the Tax Reform Act of 1986. Mimeo, M.I.T. Sloan School.

Plesko, G. A. (1996). “Gimme Shelter?” Closely Held Corporations Since Tax Reform. National Tax Journal, 48(3), 409-16.

Rettig, C. P. (2010). Tax Enforcement: Reading Tea Leaves in a Tax Gap Environment. Tax Notes, March 8, 2010, 1263-1270.

Watters, M. P., \& Burckel, D. (1991). Establishing Reasonableness of Compensation Difficult in IRS Attacks. Akron Tax Journal, 8, 147-163.

Note

Note 1. The survey is representative of the approximately 6.3 million U.S. small businesses and include nonfarm, nonfinancial for-profit businesses that have less than 500 employees and were listed on Dun's Market Identifier file as of May 2004. The survey became publicly available in September 2006. 